\title{
Myrrh-derived terpenoids as inhibitors of marine biofouling
}

\author{
Edward C. Pope ${ }^{1, *}$, Ahmed Ali' ${ }^{2}$, Sheelagh L. Conlan ${ }^{3}$, Ifor D. Bowen ${ }^{2}$, \\ Anthony S. Clare ${ }^{3}$, Andrew F. Rowley ${ }^{1}$ \\ ${ }^{1}$ Department of Environmental and Molecular Biosciences, Swansea University, Singleton Park, Swansea SA2 8PP, Wales, UK \\ ${ }^{2}$ School of Biosciences, Cardiff University, Cardiff CF10 3US, Wales, UK \\ ${ }^{3}$ School of Marine Science and Technology, Newcastle University, Newcastle upon Tyne NE1 7RU, UK
}

\begin{abstract}
With the recent ban on organotin-containing antifouling coatings by the International Maritime Organisation and doubts about paints containing copper, there is a pressing need for environmentally benign antifoulants. In the current study, we investigated the use of opoponax essential oil (scented myrrh Commiphora guidotti), its constituent terpenes/oids: ocimene, $\beta$-bisabolene, $\alpha$-bisabolol and farnesol, and sandalwood essential oil in this role. Assays using cypris larvae of the barnacle Balanus amphitrite revealed that coatings of the sesquiterpenoid alcohols (farnesol and $\alpha$-bisabolol) and sandalwood essential oil (determined by a gas chromatograph-flame ionisation detector to consist of $78.1 \%$ santolol, another sesquiterpenoid alcohol) were the most larvicidal. The $\mathrm{LC}_{50}$ values after $48 \mathrm{~h}$ were 18 (farnesol), 88 ( $\alpha$-bisabolol) and $165 \mu \mathrm{g} \mathrm{well}{ }^{-1}$ (sandalwood essential oil). No anti-settlement was observed without accompanying larvicidal activity and no synergistic effects were seen when oils were used in combination. Farnesol and $\alpha$-bisabolol exhibited very low leaching rates into assay water, suggesting that cyprid mortality may have resulted from direct contact with the coatings. Extending the duration of these assays from 48 to $120 \mathrm{~h}$ increased settlement in controls but did not reveal additional anti-settlement activity in the presence of oils. Inclusion of the settlement inducer, 3-isobutyl-1-methylxanthine (IBMX, 10 $0^{-5} \mathrm{M}$ ) increased settlement in controls and demonstrated anti-settlement activity in opoponax essential oil without any significant cyprid mortality. Field trials that incorporated opoponax essential oil or the terpenes/oids into marine paint either individually or in 1:1 mixtures did not show clear evidence of antifouling activity at the concentrations tested.
\end{abstract}

KEY WORDS: Antifouling $\cdot$ Barnacle $\cdot$ Balanus amphitrite $\cdot$ Myrrh $\cdot$ Terpene $\cdot$ Commiphora guidotti . Opoponax

\section{INTRODUCTION}

'I hate a Barnacle as no man ever did before, not even a sailor in a slow-sailing ship' Charles Darwin wrote in 1852, 6 yr into his seminal monograph on the Cirripedia (Darwin 1852). Some 150 yr later, the growth of marine life on artificial marine structures is still a key issue in the marine and aquaculture industries. Fouling increases vessel power requirements by up to $86 \%$ (Schultz 2007) and the associated rise in fuel consumption drastically affects carbon footprints and air pollution (Yebra et al. 2004). Fuel is the largest single cost in shipping (Champ 2000) and more frequent dry docking to remove biofouling is expensive, both as expenditure and loss of earnings, and generates large amounts of toxic materials (Yebra et al. 2004, Bellas 2006). Biofouling is also a severe problem for aquaculture. Aside from increasing stress on moorings, the reduction in both effective mesh size and cage volume also disrupts water flow, restricting nutrient exchange and waste removal, with detrimental effects on stock health and the local environment (Braithwaite et al. 2007). Furthermore, biofouling is a major vector for the introduction of invasive species to new ecosystems, 
which is an area of increasing environmental concern (Gollasch 2002).

The biofouling issue was believed to have been solved, on vessels at least, with the advent of tributyltin (TBT) self-polishing copolymer paints, which is the most successful antifouling system to date (Yebra et al. 2004). A decadal study of the global shipping fleet from 1976 to 1986, when these paints were in their heyday, estimated annual fuel savings of 7.36 million $t$ ( 20 million $\mathrm{t}$ of greenhouse gas) and total yearly savings of US\$ 3 billion (Milne 1989 in Townsin 2003). Unfortunately, these coatings had severe detrimental effects on nontarget species at much lower concentrations than ever anticipated (Alzieu et al. 1986, Bryan et al. 1986). Exposure to these coatings induced imposex (male characteristics in female genitalia) in gastropods, especially in the dog whelk Nucella lapillus (Bryan et al. 1986). It also caused reproductive failure and shell malformation in the Pacific oyster Crassostrea gigas (Alzieu et al. 1986, Alzieu 2000) that resulted in the collapse of the shellfish industry in Arcachon Bay, France from 1977 to 1983 (Alzieu 2000). The International Maritime Organisation (IMO) announced a ban on the use of TBT in 2003 when TBTbased products made up $>80 \%$ of the global antifouling paints market (Scott 1999). Paints containing copper have now largely replaced TBT-based coatings (Trentin et al. 2001) and present a much reduced risk compared to TBT (Hall \& Anderson 1999). However, observations of higher copper concentrations in water, sediments and biological tissues close to marinas and harbours (Claisse \& Alzieu 1993, Srinivasan \& Swain 2007) and increasing regulatory pressure on copper containing paints (Champ 2000) have caused intensified research into alternative, environmentally benign antifoulants.

Resin from Commiphora myrrha (=C. molmol) obtained as an exudate and known as myrrh, has been important culturally and commercially since ancient times (Zhu et al. 2003, Marongiu et al. 2005). Traditionally used for embalming and incense (Zhu et al. 2003), it is now a common ingredient in food, drinks, perfumes, cosmetics, toothpaste and mouthwash (Zhu et al. 2003, Marongiu et al. 2005), with anecdotal evidence for its use as an antifoulant (Watt \& Sellar 1996). The essential oils and exudates of myrrh and scented myrrh (C. guidotti; here called opoponax) are rich in terpenoids (Baser et al. 2003, Zhu et al. 2003). Terpenoid compounds act as signalling moieties in a wide range of animal and plant phyla and play an important role in plant defence against pathogenicity and insect predation (Tholl 2006). Given the similarities between insect and crustacean physiology (Nagaraju 2007), the use of myrrh-derived terpenoids to prevent fouling by marine crustaceans is worthy of exploration.
The present studies followed initial work identifying the constituent terpenes/oids in opoponax essential oil and potential anti-settlement effects of myrrh and opoponax (Bowen \& Ali unpubl. data). Coatings of opoponax essential oil or individual terpenes/oids were tested for larvicidal or anti-settlement activity against cypris larvae of the ubiquitous tropical/semitropical barnacle Balanus amphitrite (Darwin). Chemicals that yielded promising results were then used in field trials at 2 locations in the Swansea Bay area of South Wales, UK.

\section{MATERIALS AND METHODS}

Animals. Cypris larvae of Balanus amphitrite (=Amphibalanus amphitrite Clare \& Hoeg 2008) were cultured from adult brood stock as described previously (Vogan et al. 2003). This final larval stage ( $\sim 500 \mu \mathrm{m}$ carapace length) is a nonfeeding, freeswimming form that is highly specialised for the location of a suitable settlement site.

Materials. The compounds 3-isobutyl-1-methylxanthine (IBMX), $\alpha$-bisabolol, cis- and trans-farnesol, opoponax essential oil and sea salts were purchased from Sigma-Aldrich. Samples of $\beta$-bisabolene and trans$\beta$-ocimene were provided by R. C. Treatt (Bury St Edmunds, UK). Chlorinated rubber primer SM05 as well as normal and placebo Shiprite Sailing paint were purchased from Bradite Paints. HPLC-grade ethanol and hexane were bought from Fisher. East Indian sandalwood (Santalum album) essential oil was provided by Tisserand and was determined, using a gas chromatograph-flame ionisation detector (GC-FID), to contain the sesquiterpenoid alcohol santolol at a concentration of $78.1 \%$.

Settlement assays. Following the method of Hellio et al. (2005), ethanol-washed sponge was used to coat Iwaki flat-bottomed 24-well plates (Barloworld Scientific) with chemicals at known concentrations in absolute ethanol. Control wells were coated with distilled water or ethanol. The ethanol and distilled water controls were then evaporated to dryness overnight in a fume hood at room temperature. Artificial seawater (ASW; $1 \mathrm{ml}$ ) was added to each well, then $10 \pm 2$ cyprids (age: $3 \mathrm{~d}$ ) in ASW were added and the final volume made up to $2 \mathrm{ml}$. All experimental conditions were replicated $4 \times$ on each plate. The number of cyprids per well was kept at $10 \pm 2$ because the settlement of Day 3 cyprids is density-dependent (Clare et al. 1994). Similarly, only Day 3 cyprids were used since settlement ability is strongly influenced by age (Rittschof et al. 1984, Crisp 1988). Experimental concentrations were prepared volumetrically and are expressed as $\mu \mathrm{g}$ well $^{-1}$ since the uniformity of the coating across the available surface area is unknown. For simple com- 
parisons, $2 \mathrm{ml} \mathrm{ASW}$ well $^{-1}$ gave an available surface area of $7.05 \mathrm{~cm}^{2}\left(1.89 \mathrm{~cm}^{2}\right.$ base $+5.16 \mathrm{~cm}^{2}$ curved surface) and the highest concentration $\left(\sim 2000 \mu \mathrm{g} \mathrm{well}{ }^{-1}\right)$ is a $1 \%$ volumetric dilution. Plates were incubated at $28^{\circ} \mathrm{C}$ in the dark and the number of floating, active, settled, metamorphosed and dead larvae was recorded after 24 and $48 \mathrm{~h}$ (see Crisp 1988 for a detailed description of Balanus amphitrite settlement). Data are presented as the percentage of active, dead and settled (settled and metamorphosed combined) cyprids. Later experiments recorded these values for incubations up to $120 \mathrm{~h}$ or included the settlement inducer IBMX. IBMX in ethanol was added to ASW to produce a final concentration of $10^{-5} \mathrm{M}$ before $2 \mathrm{ml}$ of the solution was added to each well. Ten \pm 2 cyprids (age: $3 \mathrm{~d}$ ) in a minimum of ASW were then added. Mean values were calculated from the replicates and each experiment was repeated with several different batches of cyprids.

Leaching experiments. Iwaki plates were prepared with the maximum concentrations of farnesol and $\alpha$-bisabolol (2215 and $2325 \mu \mathrm{g}$ well $^{-1}$, respectively) together with ASW and ethanol controls. ASW (2 ml) was added to each well in the absence of cyprids and incubated at $28^{\circ} \mathrm{C}$ in the dark. The ASW was removed after $24 \mathrm{~h}, 48 \mathrm{~h}$ or $7 \mathrm{~d}$ and extracted using hexane. Four wells were sampled for each treatment at each time. An equal volume of hexane was added to the ASW and the top layer was aspirated with a glass pipette into a small, clean, glass vial. This process was repeated and the 2 volumes of hexane solvent were combined. The solvent was then evaporated under nitrogen and stored at $-20^{\circ} \mathrm{C}$ for GC-FID analysis.

GC-FID analysis. Samples were reconstituted in absolute ethanol (1 ml), vortex mixed at high speed ( $2 \mathrm{~min})$ and filtered $(0.2 \mu \mathrm{m})$ to remove any salts. The solvent was then removed under nitrogen and the samples resuspended in $200 \mu \mathrm{l}$ of ethanol. Standard stocks of farnesol and $\alpha$-bisabolol in absolute ethanol were prepared and serially diluted to yield a standard curve concentration range of 0 to $200 \mu \mathrm{g} \mathrm{ml}^{-1}$. Samples were analysed using an Agilent 6890N gas chromatograph (Agilent Technologies) equipped with a flame ionisation detector and an Agilent 7683 autosampler. Separation was performed on a $5 \%$ phenyl methyl siloxane (DB-5) fused-silica capillary column (30 $\mathrm{m} \times 0.32 \mathrm{~mm}$ i.d., df $=0.25 \mu \mathrm{m}$ ) with a temperature gradient of $1^{\circ} \mathrm{C}$ $\mathrm{min}^{-1}$ from 140 to $170^{\circ} \mathrm{C}$, followed by a gradient of $50^{\circ} \mathrm{C} \mathrm{min}^{-1}$ to a final oven temperature of $250^{\circ} \mathrm{C}$. Helium was used as the carrier gas with a constant flow of $1 \mathrm{ml} \mathrm{min}{ }^{-1}$. Injector and source temperatures were 250 and $350^{\circ} \mathrm{C}$ respectively. Standards and samples $(5 \mu \mathrm{l})$ were injected in duplicate.

Field trials. Two locations were selected: (1) an exposed site at the base of Mumbles Lifeboat Station $\left(51^{\circ} 34^{\prime} 11.84^{\prime \prime} \mathrm{N}, 3^{\circ} 58^{\prime} 32.43^{\prime \prime} \mathrm{W}\right)$ and (2) a sheltered site in Swansea Marina (5136' 54.98" N, 356' 20.10" W). Robust frames were made from $55 \mathrm{~mm}$ PVC tubing for Site 1 while less substantial $25 \mathrm{~mm}$ PVC tubing was used at Site 2. Two settlement substrates were used: ceramic tiles (B\&Q, Perlato wall tiles, $152 \times 76 \times 9 \mathrm{~mm}$ ) and steel panels (Q-Panel Lab Products, type S, $152 \times$ $102 \times 0.8 \mathrm{~mm}$ ). A special formulation of a vinyl acrylic self-polishing copolymer ablative antifouling paint (Shiprite Sailing) that contained no biocides was obtained from Bradite Paints. Oils were added individually or in combination with this placebo paint as detailed in Table 1. Positive and negative controls were the normal antifouling paint and the placebo paint respectively. Painting was performed following the manufacturer's instructions. Substrates were cleaned with thinners, painted with several layers of primer and then coated with several layers of paint, each containing known concentrations of oils. Substrates were prepared in triplicate for both locations. Frames were secured to a concrete structure at the same depth in the exposed site and suspended at a depth of $\sim 1$ to $2 \mathrm{~m}$ at the sheltered site.

Statistical analyses. Data are presented throughout either as mean values $\pm /+$ SE or $\pm 95 \%$ CI. Statistical analyses were performed using GraphPad Prism 5.00 for Windows (GraphPad Software). Percentages were arcsine transformed and analysed against the ethanol control using 2-way ANOVA with Bonferroni post-test.

\section{RESULTS}

\section{Settlement assays}

The effects of coatings of differing concentrations of opoponax and sandalwood essential oils, 2 terpenes (ocimene and $\beta$-bisabolene) and 2 sesquiterpenoid alcohols ( $\alpha$-bisabolol and farnesol) on Balanus amphi-

Table 1. Field trial treatments. Each treatment was replicated 3 times on 2 different substrates at each location. For $1 \%$ mixes, a $1: 1(\mathrm{v} / \mathrm{v})$ mixture was produced and added to the placebo paint at a concentration of $1 \%(\mathrm{v} / \mathrm{v})$

\begin{tabular}{|ll|}
\hline Experiment & \multicolumn{1}{c|}{ Treatment } \\
\hline 1 & Positive control (normal antifouling paint) \\
2 & Negative control (placebo paint) \\
3 & $1 \%(\mathrm{v} / \mathrm{v})$ farnesol \\
4 & $1 \%(\mathrm{v} / \mathrm{v}) \alpha$-bisabolol \\
5 & $1 \%(\mathrm{v} / \mathrm{v})$ opoponax \\
6 & $1 \%(\mathrm{v} / \mathrm{v})$ farnesol / $\alpha$-bisabolol \\
7 & $1 \%(\mathrm{v} / \mathrm{v})$ farnesol / $\beta$-bisabolene \\
8 & $1 \%(\mathrm{v} / \mathrm{v})$ farnesol / opoponax \\
9 & $1 \%(\mathrm{v} / \mathrm{v}) \alpha$-bisabolol / $\beta$-bisabolene \\
10 & $1 \%(\mathrm{v} / \mathrm{v}) \alpha$-bisabolol / opoponax \\
11 & $1 \%(\mathrm{v} / \mathrm{v}) \beta$-bisabolene / opoponax \\
\hline
\end{tabular}



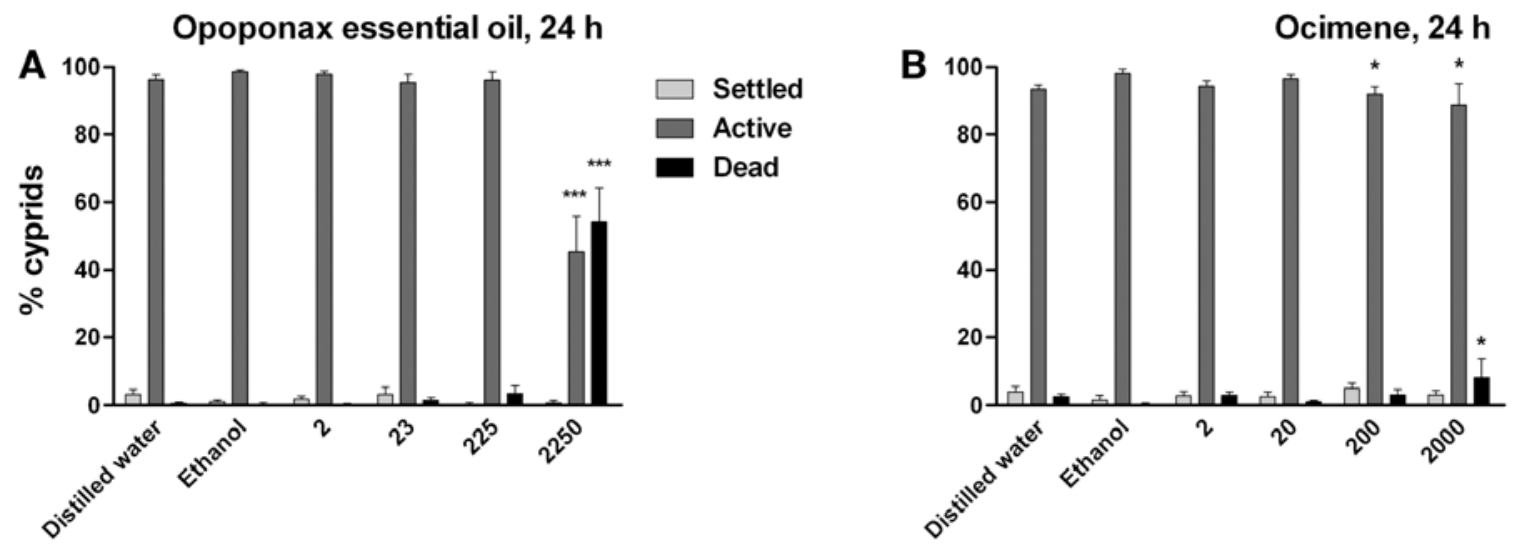

Ocimene, $48 \mathrm{~h}$

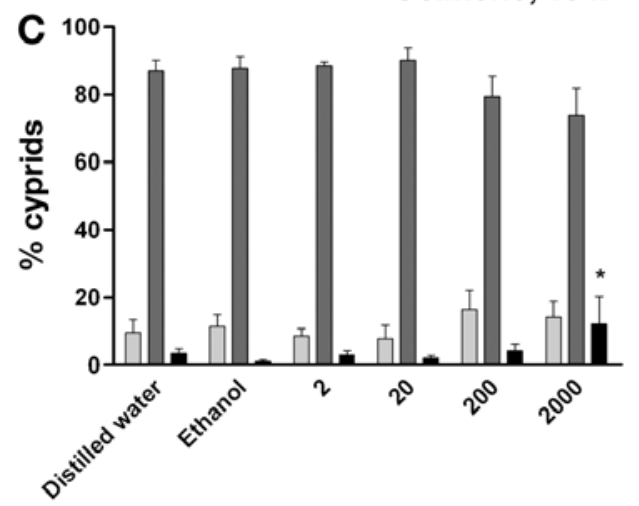

$\beta$-Bisabolene, $48 \mathrm{~h}$

Farnesol, $24 \mathrm{~h}$
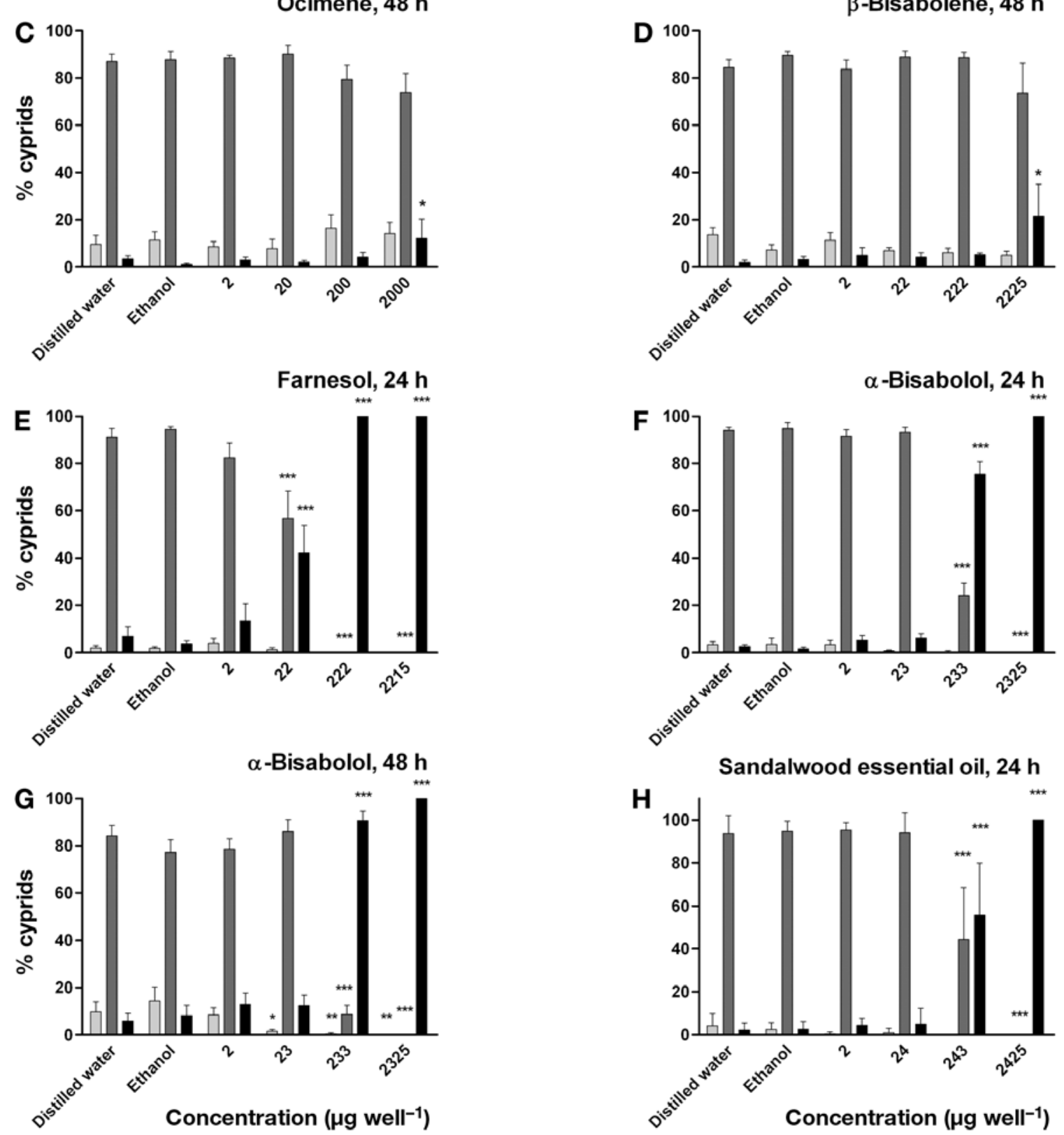

Sandalwood essential oil, $24 \mathrm{~h}$

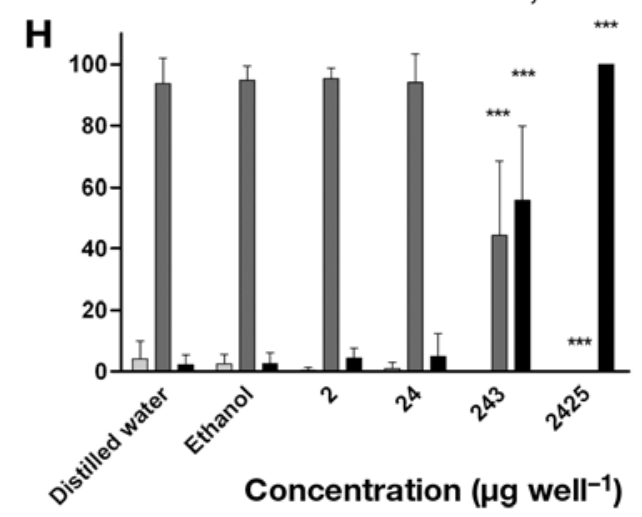

Fig. 1. Balanus amphitrite. Effects of coating 24-well plates with opoponax and sandalwood essential oils, 2 terpenes (ocimene and $\beta$-bisabolene) and 2 sesquiterpenoid alcohols ( $\alpha$-bisabolol and farnesol) on the percentage (mean + SE) of active, dead and settled cypris larvae at 24 and $48 \mathrm{~h} . \mathrm{N}=5$ to $7 ;^{* * *} \mathrm{p}<0.001,{ }^{* *} \mathrm{p}<0.01$ and ${ }^{*} \mathrm{p}<0.05$ compared with ethanol (vehicle) control (2-way ANOVA with Bonferroni post-test on arcsine transformed data) 
trite cypris larvae after 24 and $48 \mathrm{~h}$ were investigated. There was no significant difference between the control wells coated with water and those coated with ethanol (vehicle) in any experiment. Dilutions of opoponax essential oil showed larvicidal effects compared to the ethanol control after $24 \mathrm{~h}(\mathrm{p}<0.001)$ at the highest concentration tested (2250 $\mathrm{ug}_{\mathrm{g}} \mathrm{well}^{-1}$; Fig. 1A). Similarly, the monoterpene ocimene caused an increase in cyprid mortality $(\mathrm{p}<0.05)$ after $24 \mathrm{~h}$ at $2000 \mu \mathrm{g}$ well $^{-1}$ and a slight, but significant $(p<0.05)$ reduction in the percentage of active cyprids at $200 \mu \mathrm{g} \mathrm{well}^{-1}$ (Fig. 1B) that became insignificant after $48 \mathrm{~h}$ (Fig. 1C). The sesquiterpene $\beta$-bisabolene caused a significant increase in the percentage of dead cyprids only at the highest concentration (2225 $\mu \mathrm{g}$ well $^{-1}$ ) and after $48 \mathrm{~h}$ (Fig. 1D). The sesquiterpenoid alcohols displayed considerably greater larvicidal activity. Both farnesol and $\alpha$-bisabolol caused $100 \%$ mortality at a concentration of $\sim 2200$ to $2300 \mu \mathrm{g}$ well ${ }^{-1}$ after $24 \mathrm{~h}$ (Fig. 1E,F). Farnesol also caused $100 \%$ mortality after $24 \mathrm{~h}$ at $222 \mu \mathrm{g}$ well ${ }^{-1}$ and $42 \%$ mortality at $22 \mu$ well $^{-1}$ (Fig. 1E), which rose to $59 \%$ after $48 \mathrm{~h}$ ( $\mathrm{p}<0.001$, data not shown). A coating of $233 \mu \mathrm{g} \mathrm{well}^{-1}$ of $\alpha$-bisabolol caused $75 \%$ mortality after $24 \mathrm{~h}$ (Fig. 1F), which increased to $91 \%$ after $48 \mathrm{~h}$ (Fig. 1G), at which time an anti-settlement effect $(p<0.05)$ was observed at $23 \mu \mathrm{g}$ well ${ }^{-1}$ with no significant increase in cyprid mortality (Fig. 1G). Sandalwood oil, which had been determined to contain a high concentration of the sesquiterpene alcohol santolol, caused similar levels of barnacle mortality, with $100 \%$ mortality at $2425 \mu \mathrm{g}$ well $^{-1}$ and $56 \%$ mortality at $243 \mu \mathrm{g}$ well $^{-1}$ after $24 \mathrm{~h}$ (Fig. $1 \mathrm{H}$ ), the latter rising to $68 \%$ after $48 \mathrm{~h}$ (data not shown) ( $\mathrm{p}<0.001$ for both 24 and $48 \mathrm{~h}$ incubations at $243 \mu \mathrm{g}$ well $\left.^{-1}\right)$.

$\mathrm{LC}_{50}$ values, defined as the concentration ( $\mu \mathrm{g}$ well ${ }^{-1}$ ) that killed $50 \%$ of the cyprids, were calculated after 24 and $48 \mathrm{~h}$ for the terpenes/oids and essential oils that elicited a response sufficient for analysis (Fig. 2, Table 2). Farnesol, the most lethal coating, exhibited a $\mathrm{LC}_{50}$ value of $18 \mu \mathrm{g} \mathrm{well}{ }^{-1}$ after $48 \mathrm{~h}$. The other
Table 2. $\mathrm{LC}_{50}$ values $\left(\mu \mathrm{g}\right.$ well ${ }^{-1}$ ) for treatments that elicited a sufficient response. $95 \%$ CIs in parentheses

\begin{tabular}{|lrc|}
\hline Treatment & $24 \mathrm{~h}$ & $48 \mathrm{~h}$ \\
\hline$\alpha$-Bisabolol & $122(77-91)$ & $88(43-179)$ \\
Farnesol & $35(15-82)$ & $18(6-51)$ \\
Sandalwood essential oil & $255(140-464)$ & $165(78-346)$ \\
\hline
\end{tabular}

sesquiterpenoid alcohol, $\alpha$-bisabolol, and sandalwood oil displayed $\mathrm{LC}_{50}$ values of 88 and $165 \mu \mathrm{g} \mathrm{well}{ }^{-1}$ respectively after $48 \mathrm{~h}$.

Drastic morphological changes were observed in some larvae, mainly when exposed to the sesquiterpenoid alcohols and sandalwood oil, although effects were also occasionally observed with higher concentrations of opoponax essential oil, ocimene and $\beta$-bisabolene. Fig. 3A shows a normal Balanus amphitrite cypris larva compared with several cyprids incubated for $24 \mathrm{~h}$ in a well coated with $222 \mu \mathrm{g}$ farnesol (Fig. 3B). The most notable morphological changes associated with exposure to these compounds were the extension of the thoracic limbs (thoracic prolapse sensu Crisp 1988) and the development of a protuberance resembling a fluid-filled sac posterior to the thoracoabdomen (Fig. 3B). Protuberances with similar fluidfilled appearances were also frequently seen ventrally, close to the first thoracic limb and anteriorly, where they often bore the antennules and compound eyes (Fig. 3B).

Potential synergistic effects were investigated using the 6 possible 1:1 mixtures of opoponax essential oil, $\beta$-bisabolene, farnesol and $\alpha$-bisabolol. The individual components of the mixtures were used as controls at twice the maximum mixture concentration (i.e. where the highest mixture concentration was $200 \mu \mathrm{g}$ of component $\mathrm{a}+200 \mu \mathrm{g}$ of component $\mathrm{b}, 2$ positive controls consisting of $400 \mu \mathrm{g}$ of a and $400 \mu \mathrm{g}$ of b were used). Mixtures of oils did not show greater anti-settlement or larvicidal activity than their individual components. For example, a combination of the 2 most potent ingredients farnesol and $\alpha$-bisabolol caused $100 \%$ mortality after $24 \mathrm{~h}$ at a concentration of $\sim 220$ to $230 \mu \mathrm{g}$ well ${ }^{-1}$ that corresponded with the controls $(100 \%$ mortality with $443 \mathrm{\mu g}$ farnesol well ${ }^{-1}$ and $69.9 \pm 18.6 \%$ mortality with $465 \mu \mathrm{g}$ $\alpha$-bisabolol well-1) but no significant mortality was noted at lower concentrations ( 20 and $2 \mu \mathrm{g}$ each well ${ }^{-1}$ ). The combination of farnesol and $\alpha$-bisabolol was also investigated at much lower concentrations ( 20 to $200 \mathrm{ng}$ each well $^{-1}$ ) but no additive effects on settlement or mortality were observed (data not shown).
Fig. 2. Balanus amphitrite. Survival curves at $48 \mathrm{~h}$ for cyprids exposed to different concentrations of terpenes/oids and essential oils

$\checkmark \alpha$-Bisabolol

$\beta$-Bisabolene

- Ocimene

- Opoponax oil

* Sandalwood oil

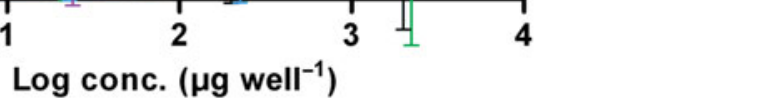



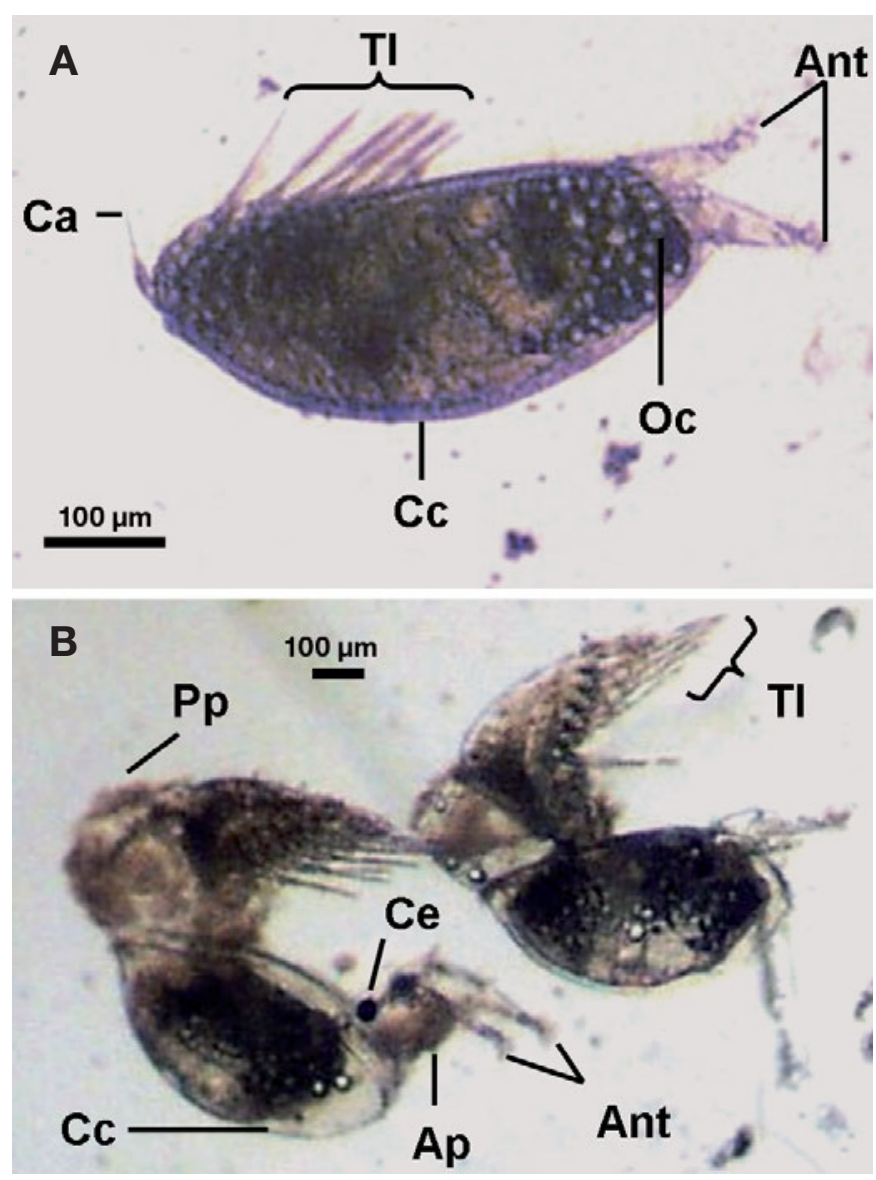

Fig. 3. Balanus amphitrite. (A) Normal appearance of nonfeeding, Day 3 cypris larva after incubation in an ethanol control. (B) Day 3 cyprids after incubation for $24 \mathrm{~h}$ with $222 \mu \mathrm{g}$ farnesol well ${ }^{-1}$. Ant, antennule; Ap, anterior protuberance; $\mathrm{Ca}$, caudal appendage; $\mathrm{Cc}$, carapace cuticle; $\mathrm{Ce}$, compound eye; Oc, oil cell; $\mathrm{Pp}$, posterior protuberance; $\mathrm{Tl}$, thoracic limbs

The settlement levels in these assays were low, raising the possibility that anti-settlement activity was masked at sublethal concentrations. Experiments with the different chemicals (except for sandalwood essential oil) were therefore run over longer time periods to increase the number of larvae that settled and metamorphosed. Barnacle settlement in controls increased from (mean $\pm \mathrm{SE}, \mathrm{N}=4$ to 7 ) $9.3 \pm 1.0 \%$ after $48 \mathrm{~h}$ to $19.0 \pm 2.0 \%, 28.1 \pm 3.0 \%$ and $32.1 \pm 3.3 \%$ after 72 , 96 and $120 \mathrm{~h}$ respectively. Despite the increased settlement at later time periods, no anti-settlement effect that was not accompanied by mortality was observed with any of the chemicals at any of the concentrations tested (data not shown).

To further investigate potential anti-settlement activity, cyprids were incubated in the presence of the settlement inducer IBMX, which has been shown to promote Balanus amphitrite settlement at $10^{-5}$ and $10^{-6} \mathrm{M}$ (Clare et al. 1995, Head et al. 2004). Incubation of $B$. amphitrite cyprids with $10^{-5} \mathrm{M}$ IBMX increased settlement in controls from from $2.5 \pm 3.5 \%$ after $24 \mathrm{~h}$ and $9.3 \pm 1.0 \%$ after $48 \mathrm{~h}$ to $46.5 \pm 2.1 \%$ and $61.7 \pm 2.0 \%$ respectively. $\alpha$-Bisabolol, farnesol and sandalwood oil, which had all caused $100 \%$ mortality at the highest concentrations tested (2215 to $2325 \mu \mathrm{g}$ well ${ }^{-1}$ ), were used at lower concentrations. All other chemicals were tested at the original concentration range of $\sim 2$ to $2000 \mu \mathrm{g}$ well $^{-1}$. The cyprid mortality observed with $2250 \mu \mathrm{g}$ opoponax oil well ${ }^{-1}$ was not evident in the presence of IBMX after either 24 or $48 \mathrm{~h}$. Instead, this concentration caused a significant reduction in settlement after $24(\mathrm{p}<0.05)$ and $48 \mathrm{~h}(\mathrm{p}<0.001)$ with no significant increase in cyprid mortality (Fig. 4). The larvicidal activity of ocimene at $2000 \mu \mathrm{g} \mathrm{well}{ }^{-1}$ was evident in the presence of IBMX after $24 \mathrm{~h}(\mathrm{p}<0.01$, data not shown) but no effect on settlement was observed at any of the concentrations tested. $\beta$-bisabolene had no effect on cyprid settlement or mortality in the presence of IBMX at any of the concentrations tested. No anti-settlement activity that was not accompanied by larvicidal activity was observed with the sesquiterpenoid alcohols or sandalwood oil (data not shown) in the presence of IBMX.

\section{Leaching experiments}

Experiments were conducted to investigate whether the sesquiterpenoid alcohols were leaching into the surrounding water in the well-based assay system. Concentrations of farnesol and $\alpha$-bisabolol were below

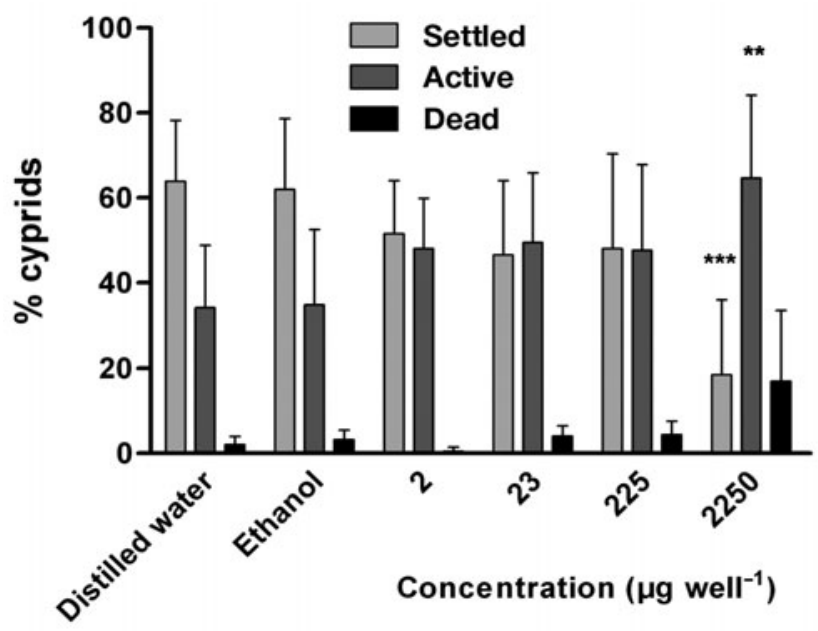

Fig. 4. Balanus amphitrite. Effects of coating 24-well plates with opoponax essential oil on the percentage (mean $+\mathrm{SE}$ ) of active, dead and settled cypris larvae in the presence of $10^{-5} \mathrm{M}$ 3-isobutyl-1-methylxanthine (IBMX) at $48 \mathrm{~h} . \mathrm{N}=5$; ${ }^{* * *} \mathrm{p}<0.001$ and ${ }^{* *} \mathrm{p}<0.01$ compared with ethanol (vehicle) control (2-way ANOVA with Bonferroni post-test on arcsine transformed data) 
detectable levels $\left(0.16\right.$ and $0.04 \mu \mathrm{g} \mathrm{ml}^{-1}$ for farnesol and $\beta$-bisabolol respectively) after 24 and $48 \mathrm{~h}$. After 7 $\mathrm{d}$, the maximum concentrations of $\alpha$-bisabolol and farnesol detected in ASW were 2.06 and $11.86 \mu \mathrm{g} \mathrm{ml}^{-1}$ respectively, indicating maximum leaching rates of 0.18 and $1.1 \%$ in $7 \mathrm{~d}$.

\section{Field trials}

Frames were secured at Mumbles Pier in April 2007. After $7 \mathrm{wk}$ of immersion, the positive control plates (normal antifouling paint) were free from fouling but there was moderate to heavy settlement of the barnacle Semibalanus balanoides on the other plates, without significant differences between treatments and the negative control. The presence of a terete, cartilaginous and often bleached alga, putatively identified as a species of Gracilaria, was noted. As the period of immersion increased, the positive controls showed little or no cover while fouling occurred on all other plates. After $18 \mathrm{wk}$ of immersion, all experimental and negative control plates were heavily fouled with $S$. balanoides and the alga (Fig. 5). Dense clumps of the hydroid Obelia dichotoma were frequently observed and bryozoans were common, especially Bugula plumosa, although Bicellaria ciliata and the encrusting Cryptosula pallasiana were also found. A variety of algal, hydroid, crustacean and molluscan species were sporadically observed, the most common of which were the algae Ulva intestinalis and Porphyra purpurea, the tubeworm Pomatoceros triqueter and juvenile blue mussels Mytilus edulis. The plates were retrieved by the end of August to enable more detailed analysis and species identification. No significant antifouling effects were noted in any of the treatments. A full species list for Mumbles Pier is given in Table 3.

Frames were immersed at Swansea Marina in May 2007. The development of colonies of the encrusting bryozoan Conopeum reticulum was evident after $7 \mathrm{wk}$ of immersion. These were succeeded by the serpulid tubeworm Ficopomatus enigmatus, which was present in large numbers after $16 \mathrm{wk}$. Individual specimens of the barnacle Balanus crenatus were also observed. F. enigmatus settlement was depth-dependent, with deeper plates suffering much greater fouling. As the controls for some of the treatments were suspended at shallower depths, this depth effect reduced the power

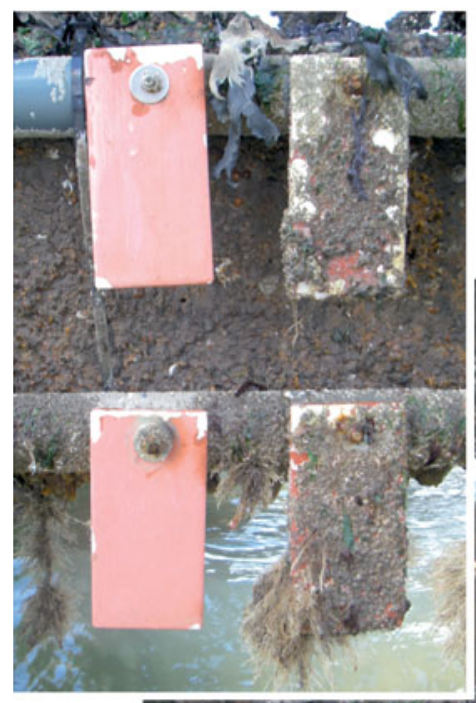

Fig. 5. In situ settlement frames at Mumbles Pier after $18 \mathrm{wk}$ immersion. Second frame is shown in the background. A third settlement frame is secured to the farthest strut, facing the other direction. Treatments were replicated $3 \times$ at each location on 2 substrates: steel panels and ceramic tiles. The lead frame shows 2 replicate rows of tiles with experimental numbers (see Table 1) from left to right. The positive controls are barren while all other tiles are heavily fouled by the barnacle Semibalanus balanoides and algae. Inset shows greater detail of the positive (left) and negative (right) controls

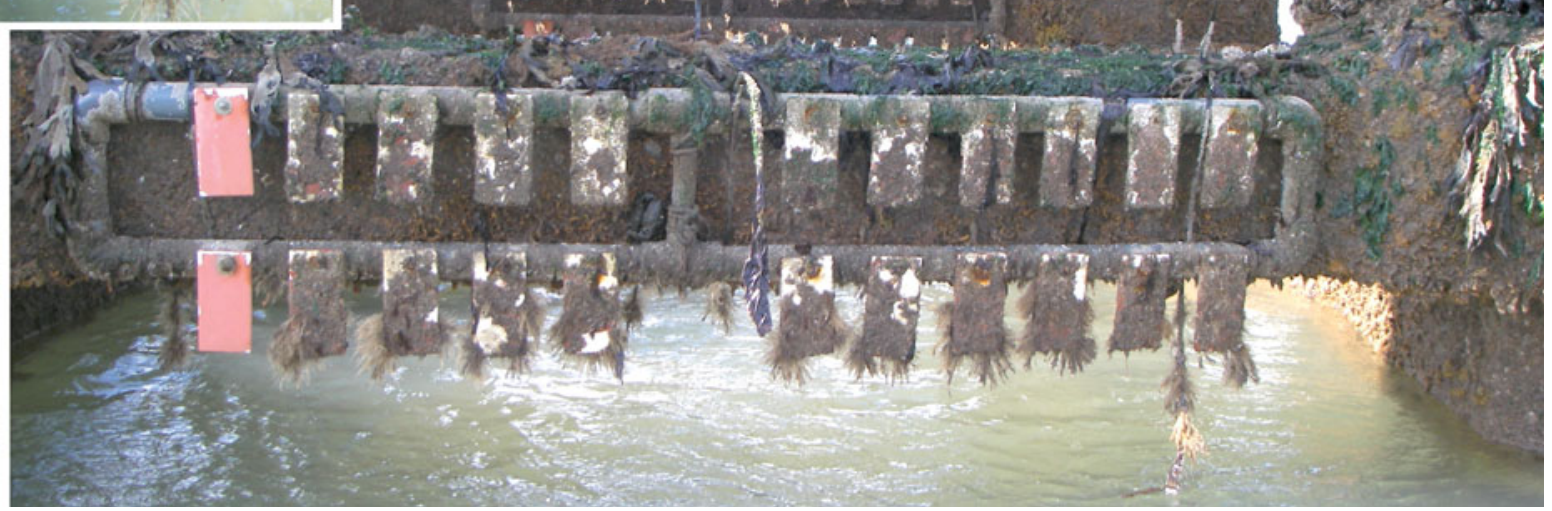


Table 3. Species list for organisms identified on plates secured at Mumbles Pier from April to August 2007

\begin{tabular}{|ll|}
\hline & Details \\
\hline Algae & \\
Cladophora rupestris & Green alga (Chlorophycae) \\
Ulva intestinalis & \\
Desmarestia aculeata & Brown alga (Phaeophycae) \\
Halopteris filicina & \\
Spongonema tomentosum & \\
Ceramium rubrum & Red alga (Rhodophycae) \\
Gracilaria spp. & \\
Lomentaria orcadensis & \\
Porphyra purpurea & \\
Filamentous form(s) & \\
Cnidaria & \\
Diadumene cf. cincta & Anemone \\
Aglaophenia pluma & Hydroid \\
Diphasia rosacea & \\
Obelia dichotoma & \\
Obelia geniculata & \\
Annelida & \\
Pomatoceros triqueter & Tubeworm (Serpulidae) \\
Crustacea & \\
Elminius modestus & Barnacle \\
Semibalanus balanoides & \\
Caprella linearis & Amphipod; in Bugula fronds \\
Cancer pagurus & Crab; in algae \\
Mollusca & \\
Mytilus edulis & \\
Crepidula fornicata & Gastropod \\
Bryozoa & \\
Bicellaria ciliata & \\
Bugula plumosa & \\
Cryptosula pallasiana & Encrusting \\
Ascidiacea & \\
Ascidiella scabra & \\
Didemnid asicidan & Encrusting \\
\hline
\end{tabular}

of statistical analyses to detect antifouling activity. Variations in depth on the frames at Mumbles Pier were much less $(<30 \mathrm{~cm})$ and these frames were designed with controls at both depths (see Fig. 5). No significant antifouling effects were noted for any of the treatments at Swansea Marina. However, some ceramic tiles (but not steel panels) treated with opoponax essential oil appeared to have less fouling than other experimental panels at the same depth.

\section{DISCUSSION}

The settlement assays revealed that opoponax essential oil and its constituent terpenes/oids exhibit varying levels of larvicidal activity to Balanus amphitrite cyprids. However, no anti-settlement activity was observed at nonlethal concentrations in these experiments. Larvicidal and anti-settlement activity observed did not translate to antifouling in the field.

The sesquiterpenoid alcohols caused much greater cyprid mortality than any of the other chemicals tested, with farnesol being the most lethal. Previous work has shown that farnesol solutions in seawater inhibit Balanus amphitrite settlement with a mean $\mathrm{EC}_{50}$ median effect concentration to inhibit $50 \%$ of settlement value of $1.37 \mathrm{ppm}$ after $24 \mathrm{~h}$ (Willemsen et al. 1998). These authors dissolved farnesol in dimethylsulphoxide (DMSO) before making serial dilutions in seawater; thus, assuming a dimensionless interpretation of ppm, this corresponds to a concentration of $1.2 \mathrm{\mu g} \mathrm{ml} \mathrm{ml}^{-1}$. Levels of sesquiterpenoid alchohols were undetectable in the ASW after $48 \mathrm{~h}$, suggesting that mortality may have resulted from direct contact rather than dissolution. The concentrations of farnesol recorded after $7 \mathrm{~d}$ were higher than the $\mathrm{EC}_{50}$ value stated by Willemsen et al. (1998) but strict comparisons are questionable as the farnesol was dissolved in a solvent and the term ppm is open to interpretation.

Although many plants form mixtures of terpenes which are believed to be more effective deterrents (Tholl 2006), no synergistic effects were observed when opoponax essential oil, $\beta$-bisabolene, $\alpha$-bisabolol and farnesol were tested as 1:1 mixtures. Interestingly, the terpene $\beta$-bisabolene caused much less mortality than its alcohol derivative $\alpha$-bisabolol. This is in agreement with previous observations that farnesene had no effect on the settlement or mortality of Balanus amphitrite larvae while its alcohol derivative farnesol was larvicidal (Bowen \& Ali unpubl. obs.). The physical characteristics of terpenes do not markedly differ from those of their alcohol derivatives, suggesting a potential molecular mechanism for the differential effects on cyprids.

Although there was an apparent, but insignificant, dose-dependent inhibition of settlement with opoponax essential oil, no anti-settlement activity was apparent when assay duration was extended. Opoponax essential oil was also the only compound to show antisettlement activity without significant cyprid mortality in the presence of the potent settlement inducer IBMX. It is interesting that IBMX appeared to mitigate the larvicidal effect of opoponax essential oil, causing an increase in both settled and healthy, active cyprids compared to opoponax essential oil alone. All cyprids recorded as settled had normal appearances (see Crisp 1988) and this mitigation effect of IBMX was also noted with $\alpha$-bisabolol and $\beta$-bisabolene. As any anti-settlement response would need to compete with the strong pro-settlement influence of IBMX, opoponax essential oil may warrant further investigation. 
Terpenoid compounds are known to play important roles in many arthropod species, especially in insects where the sesquiterpenoid juvenile hormones regulate reproductive maturation and act as 'status quo' hormones (Riddiford 1996) favouring retention of the larval form and inhibiting metamorphosis in holometabolous forms (Laufer \& Biggers 2001). Despite the similarities between insect and crustacean life cycles, early experiments suggested that juvenile hormones did not play the same role in barnacle metamorphosis. Exposing barnacles to the juvenile hormone or its analogues instead caused precocious metamorphosis into unattached adults (Gomez et al. 1973, Mortlock et al. 1984). Juvenile hormones have not been found in any crustaceans (Nagaraju 2007) but methyl farnesoate (MF), the non-epoxidated precursor of juvenile hormone III (JHIII; the most common form), is believed to fulfill many of the same roles in crustaceans (Laufer et al. 1987, Nagaraju 2007) and has also been shown to induce premature metamorphosis in barnacles (Yamamoto et al. 1997). Smith et al. (2000) finally provided convincing evidence for MF as a bona fide barnacle juvenile hormone by demonstrating that it inhibited metamorphosis when applied at an appropriate physiological concentration $(0.1 \mu \mathrm{M})$, and that this inhibition can be reversed by returning the barnacles to normal seawater. Premature metamorphosis only occurred at pharmacological concentrations (1 to $10 \mu \mathrm{M})$ which are potentially nonrelevant physiologically (Smith et al. 2000). Furthermore, recent studies have demonstrated that compounds possessing juvenile hormonelike properties in insects also show barnacle antisettlement activity (Skattebøl et al. 2006).

Farnesol was one of the first substances identified in plant extracts to have very similar physiological activity as juvenile hormones and has also been shown to induce premature metamorphosis in barnacles (Mortlock et al. 1984). It is possible that the larvicidal activity of farnesol is connected to its structural relationship with $\mathrm{MF}$, of which it is a direct precursor. The progressively lower $\mathrm{LC}_{50}$ values observed with $\alpha$-bisabolol and sandalwood essential oil would follow their increasing structural divergence. In addition to its role as a juvenile hormone, MF has been implicated in the regulation of crustacean behaviour, general protein synthesis, morphogenesis, moulting, reproduction and osmoregulation (Nagaraju 2007). The fluid-filled protuberances in posterior, ventral and anterior structures produced upon exposure to sesquiterpenoid alcohols could signify interference with the hormonal control of osmoregulation, although direct toxicity is also likely. The appearance and locations of these protuberances closely agreed with previous observations, in which they were hypothesised to be the expelled mantle cavity lining (Mortlock et al. 1984).
Cyprids killed by exposure to a sesquiterpenoid alcohol nearly always exhibited this morphology, which was regularly accompanied by a weakly bound cuticle that detached upon any physical contact. This could signify deterioration of the adductor muscles or interaction with the moulting hormone 20-hydroxyecdysone. Ultrastructural studies have shown that exposure to farnesol causes massive tissue damage in cyprids, including damage to mitochondria and muscles (Mortlock et al. 1984) and the thoracic prolapses that were frequently observed normally accompany ruptured thorax retractor muscles (Crisp 1988). On the other hand, juvenile hormone analogues have also been demonstrated to modulate ecdysteroid activity in crustaceans (Mu \& Leblanc 2004) and MF has been shown to act via protein kinase $\mathrm{C}$ signal transduction in Balanus amphitrite (Yamamoto et al. 1997). The specificity of the reaction, with alcohol derivatives exhibiting larvicidal activity that is absent from the unmodified sesquiterpene, suggests the possible involvement of a hormonal pathway.

Preliminary field trials failed to demonstrate any effect of opoponax essential oil or the terpenes/oids on biofouling. While barnacles are the dominant macrofouling taxon worldwide (Khandeparker \& Anil 2007) and a reasonable first target in investigations into antifouling activities, over 4000 different species have been identified on fouled structures (Anderson \& Hunter 2000). It is therefore possible that this ineffectiveness in the field signified a lack of activity over a wide taxonomic range. It is interesting, however, that a barnacle (Semibalanus balanoides) was the first animal macrofouler observed on settlement plates placed at Mumbles Pier. The ingredients were added to the paint at concentrations $100 \times$ greater than those shown to be larvicidal in settlement assays and barnacle cypris larvae are known to use chemical cues during their extensive exploration of surfaces prior to settlement (Crisp \& Meadows 1962, Dreanno et al. 2006). It is likely, therefore, that the ingredients either leached out of the paint or remained locked into the formula for the duration of the trials. Although the best option available at the time, copolymer paints involve a significant level of technology and the substitution of ingredients is fraught with problems. Future field trials would benefit from more sophisticated paint formulations.

The possibility of endocrine disruption cannot be discounted. The similarity of the sesquiterpenoid alcohols to a crustacean hormone and their observed effects on the cyprids suggest that their incorporation into antifouling paint may not be advisable. However, intriguing evidence from the field trials indicates that opoponax essential oil may be worth incorporating into a more effective paint. 
Acknowledgements. This work was supported by a FollowOn Fund grant awarded by the Natural Environment Research Council (NE/E522340/1) to A.F.R., A.S.C. and I.F.D. Additional support was provided by the Welsh Institute for Sustainable Environments (WISE) Network. We thank K. Naylor for his assistance with the field trials and the construction of the settlement frames, and T. Ayre of Bradite Paints for manufacture of the placebo paint and his advice on field trials. C. Restall (Swansea University) gave advice on arthropod hormones and P. J. Hayward (Swansea University) provided invaluable help with invertebrate identification. The use of myrrh-derived terpenes for antifouling purposes is detailed in patent no. US2007264363.

\section{LITERATURE CITED}

Alzieu C (2000) Environmental impact of TBT: the French experience. Sci Total Environ 258:99-102

> Alzieu C, Sanjuan J, Deltreil JP, Borel M (1986) Tin contamination in Arcachon Bay: effects on oyster shell anomalies. Mar Pollut Bull 17:494-498

Anderson CD, Hunter JE (2000) Whither antifoulings after TBT? NAV 2000 Int Conf Ship and Shipping Res, Venice

Baser KHC, Demirci B, Dekebo A, Dagne E (2003) Essential oils of some Boswellia spp., myrrh and opopanax. Flavour Frag J 18:153-156

Bellas J (2006) Comparative toxicity of alternative antifouling biocides on embryos and larvae of marine invertebrates. Sci Total Environ 367:573-585

Braithwaite RA, Carrascosa MCC, McEvoy LA (2007) Biofouling of salmon cage netting and the efficacy of a typical copper-based antifoulant. Aquaculture 262:219-226

Bryan GW, Gibbs PE, Hummerstone LG, Burt GR (1986) The decline of the gastropod Nucella lapillus around southwest England: evidence for the effect of tributyltin from antifouling paints. J Mar Biol Assoc UK 66:611-640

Champ MA (2000) A review of organotin regulatory strategies, pending actions, related costs and benefits. Sci Total Environ 258:21-71

> Claisse D, Alzieu C (1993) Copper contamination as a result of antifouling paint regulations. Mar Pollut Bull 26:395-397

> Clare AS, Hoeg JT (2008) Balanus amphitrite or Amphibalanus amphitrite? A note on nomenclature. Biofouling 24: $55-57$

Clare AS, Freet RK, McClary M (1994) On the antennular secretion of the cyprid of Balanus amphitrite and its role as a settlement pheromone. J Mar Biol Assoc UK 74:243-250

Clare AS, Thomas RF, Rittschof D (1995) Evidence for the involvement of cyclic AMP in the pheromonal modulation of barnacle settlement. J Exp Biol 198:655-664

Crisp DJ (1988) Reduced discrimination of laboratory-reared cyprids of the barnacle Balanus amphitrite amphitrite Darwin (Crustacea Cirripedia) with a description of a common abnormality. In: Thompson MF, Sarajini R, Nagabhushanam R (eds) Marine biodeterioration. A. A. Balkema, Rotterdam, p 409-432

Crisp DJ, Meadows PS (1962) The chemical basis of gregariousness in cirripedes. Proc R Soc Lond B Biol Sci 156: $500-520$

Darwin C (1852) Letter to W. D. Fox, October 1852. Darwin Correspondence Project, Letter no. 1489, www.darwinproject. ac.uk: Accessed 22 January 2008

$>$ Dreanno C, Kiyotaka M, Dohmae N, Takio K, Hirota H, Kirby $\mathrm{RR}$, Clare AS (2006) An $\alpha_{2}$-macroglobulin-like protein is the cue to gregarious settlement of the barnacle Balanus amphitrite. Proc Natl Acad Sci USA 103:14396-14401
Gollasch S (2002) The importance of ship hull fouling as a vector of species introductions into the North Sea. Biofouling 18:105-121

> Gomez ED, Faulkner JD, Newman WA, Ireland C (1973) Juvenile hormone mimics: effect on cirriped crustacean metamorphosis. Science 179:813-814

> Hall LW, Anderson RD (1999) A deterministic ecological risk assessment for copper in European saltwater environments. Mar Pollut Bull 38:207-218

- Head RM, Berntsson KM, Dahlstrom M, Overbeke K, Thomason JC (2004) Gregarious settlement in cypris larvae: the effects of cyprid age and assay duration. Biofouling 20: 123-128

> Hellio C, Tsoukatou M, Maréchal JP, Aldred N and others (2005) Inhibitory effects of Mediterranean sponge extracts and metabolites on larval settlement of the barnacle Balanus amphitrite. Mar Biotechnol 7:297-305

Khandeparker L, Anil AC (2007) Underwater adhesion: the barnacle way. Int J Adhes Adhes 27:165-172

> Laufer H, Biggers WJ (2001) Unifying concepts learned from methyl farnesoate for invertebrate reproduction and postembryonic development. Am Zool 41:442-457

> Laufer H, Landau M, Homola E, Borst DW (1987) Methyl farnesoate: its site of synthesis and regulation of secretion in a juvenile crustacean. Insect Biochem 17:1129-1131

Marongiu B, Piras A, Porcedda S, Scorciapino A (2005) Chemical composition of the essential oil and supercritical $\mathrm{CO}_{2}$ extract of Commiphora myrrha (Nees) Engl. and of Acorus calamus L. J Agric Food Chem 53:7939-7943

> Mortlock AM, Fitzsimons JTR, Kerkut GA (1984) The effects of farnesol on the late stage nauplius and free swimming cypris larvae of Elminius modestus (Darwin). Comp Biochem Physiol A 78:345-357

Mu XY, Leblanc GA (2004) Cross communication between signaling pathways: juvenoid hormones modulate ecdysteroid activity in a crustacean. J Exp Zool 301A:793-801

- Nagaraju GPC (2007) Is methyl farnesoate a crustacean hormone? Aquaculture 272:39-54

> Riddiford LM (1996) Juvenile hormone: the status of its 'status quo' action. Arch Insect Biochem Physiol 32:271-286

Rittschof D, Branscomb ES, Costlow JD (1984) Settlement and behavior in relation to flow and surface in larval barnacles Balanus amphitrite Darwin. J Exp Mar Biol Ecol 82: 131-146

> Schultz MP (2007) Effects of coating roughness and biofouling on ship resistance and powering. Biofouling 23:331-341

Scott A (1999) Biocides-IMO agrees on tributyl tin ban. Chem Week 161:24

Skattebøl L, Nilsen NO, Stenstrøm Y, Andreassen P, Willemsen $P$ (2006) The antifouling activity of some juvenoids on three species of acorn barnacle Balanus. Pest Manag Sci 62:610-616

Smith PA, Clare AS, Rees HH, Prescott MC, Wainwright G, Thorndyke MC (2000) Identification of methyl farnesoate in the cypris larva of the barnacle Balanus amphitrite and its role as a juvenile hormone. Insect Biochem 30:885-890

> Srinivasan M, Swain GW (2007) Managing the use of copperbased antifouling paints. Environ Manage 39:423-441

> Tholl D (2006) Terpene synthases and the regulation, diversity and biological roles of terpene metabolism. Curr Opin Plant Biol 9:297-304

Townsin RL (2003) The ship hull fouling penalty. Biofouling 19:9-15

Trentin I, Romairone V, Marcenaro G, De Carolis G (2001) Quick test methods for marine antifouling paints. Prog Org Coat 42:15-19

Vogan CL, Maskrey BH, Taylor GW, Henry S, Pace-Asciak 
CR, Clare AS, Rowley AF (2003) Hepoxilins and trioxilins in barnacles: an analysis of their potential roles in egg hatching and larval settlement. J Exp Biol 206:3219-3226

Watt M, Sellar W (1996) Frankincense and myrrh. C. W. Daniel, Saffron Walden

Willemsen PR, Overbeke K, Suurond A (1998) Repetitive testing of TBTO, sea nine 211 and farnesol using Balanus amphitrite (Darwin) cypris larvae: variability in larval sensitivity. Biofouling 12:133-147

Yamamoto H, Okino T, Yoshimura E, Tachibana A, Shimizu

Editorial responsibility: David Fields,

West Boothbay Harbor, Maine, USA
K, Fusetani N (1997) Methyl farnesoate induces larval metamorphosis of the barnacle Balanus amphitrite via protein kinase C activation. J Exp Zool 278:349-355

Yebra DM, Kiil S, Dam-Johansen K (2004) Antifouling technology - past, present and future steps towards efficient and environmentally friendly antifouling coatings. Prog Org Coat 50:75-104

Zhu NQ, Sheng SQ, Sang SM, Rosen RT, Ho CT (2003) Isolation and characterization of several aromatic sesquiterpenes from Commiphora myrrha. Flavour Frag J 18:282-285

Submitted: June 2, 2008; Accepted: October 24, 2008

Proofs received from author(s): November 24, 2008 